\title{
PENERAPAN MEDIA KOMIK PADA PEMBELAJARAN MATEMATIKA DI SEKOLAH DASAR
}

\section{Nursiwi Nugraheni ${ }^{\bowtie}$}

Prodi Pendidikan Guru Sekolah Dasar, Fakultas Ilmu Pendidikan

Universitas Negeri Semarang, Indonesia

\section{Info Artikel}

Sejarah Artikel:

Diterima Februari 2017

Disetujui Mei 2017

Dipublikasikan Juni 2017

Keywords:

comic media implementation

\begin{abstract}
This study aims to determine: (1) how to implement comic media of mathematics learning in primary school, (2) whether the comic media can help in improving the quality of mathematics learning in primary schools. This research is a qualitative research. This research contains of three sub researches. The comic media that is implemented is an educational comic media. The comic media is implemented in CTL with talking stick variation, Pjbl model with bamboo dancing variation, and CTL model with snowball throwing variation. Comic media developed adapted to the learning model used. Because the learning model used is different, the mathematics learning syntax of the three sub researches is also different. The three sub researches obtaining the same result. Comic media can help in improving the quality of mathematics learning in elementary school even though implemented with different learning model. The conclusions of this research are (1), Comics are given at the beginning of the lesson and students try to understand the material and construct the concept through comics.,(2) Comic media can assist in improving the quality of mathematics learning.
\end{abstract}

\begin{abstract}
Abstrak
Penelitian ini bertujuan untuk mengetahui: (1) bagaimana penerapan media komik dalam pembelajaran matematika sekolah dasar, (2) apakah media komik dapat membantu dalam peningkatan kualitas pembelajaran matematika di sekolah dasar. Penelitian ini merupakan penelitian kualitatif. Penelitian ini terdiri dari tiga penelitian yang dipayungi.Media komik yang diimplementasikan merupakan media komik pendidikan. Media komik tersebut diimplementasikan dalam model CTL variasi talking stick, model Pjbl variasi bamboo dancing, dan model CTL variasi snowball throwing. Media komik yang dikembangkan disesuaikan dengan model pembelajaran yang digunakan. Karena model pembelajaran yang digunakan berbeda maka sintaks pembelajaran matematika dari ketiga penelitian ini juga ada perbedaan. Dari ketiga penelitian yang dipayungi memperoleh hasil yang sama. Media komik dapat membantu dalam peningkatan kualitas pembelajaran matematika di sekolah dasar meskipun diimplementasikan dengan model pembelajaran yang berbeda. Simpulan dari penelitian ini adalah (1) Komik diberikan pada awal pembelajaran dan siswa diminta untuk memahami materi dan mengkonstruk konsep melalui komik. (2) Media komik dapat membantu dalam peningkatan kualitas pembelajaran matematika.
\end{abstract}

(C) 2017 Universitas Muria Kudus
p-ISSN 2087-9385

e-ISSN 2528-696X

Program Studi Pendidikan Guru Sekolah Dasar

Fakultas Keguruan dan Ilmu Pendidikan Universitas Muria Kudus

Kampus UMK Gondangmanis, Bae Kudus Gd. L. 1t I PO. BOX 53

Kudus

Tlp (0291) 438229 ex.147 Fax. (0291) 437198

E-mail: nursiwi@mail.unnes.ac.id 


\section{PENDAHULUAN}

Matematika merupakan ratunya ilmu. Dalam Matematika membahas fakta-fakta, hubungan-hubungannya, serta membahas problem ruang dan waktu. Dengan begitu matematika dapat menolong manusia menafsirkan secara eksak berbagai ide dan kesimpulan. Materi pembelajaran matematika di sekolah dasar adalah bilangan, geometri, pengukuran dan pengolahan data. Berdasarkan temuan Depdiknas (2007), proses pembelajaran matematika masih menunjukkan hasil yang kurang memuaskan. Pembelajaran yang digunakan masih konvensional dengan metode ceramah dan berdasarkan pada materi buku pegangan. Pembelajaran matematika juga tanpa disertai dengan media pembelajaran. Hal ini berdampak negatif terhadap daya serap peserta didik yang rendah. Menurut Bruner (dalam Winataputra, 2008) pada dasarnya belajar merupakan proses kognitif yang terjadi dalam diri seseorang. Ada tiga proses kognitif yang terjadi dalam belajar, salah satunya yaitu proses perolehan informasi baru, dapat terjadi melalui kegiatan membaca, mendengarkan penjelasan guru mengenai materi yang diajarkan atau mendengar/melihat audiovisual, dan lain-lain. Dalam pembelajaran matematika yang abstrak, siswa memerlukan alat bantu berupa media pembelajaran untuk memperoleh informasi baru tentang materi yang diajarkan. Dalam pelaksanaan proses pembelajaran matematika tersebut diperlukan media pembelajaran yang bertujuan untuk membantu guru menyampaikan materi. Media pembelajaran adalah alat atau wahana yang digunakan pendidik dalam proses pembelajaran untuk membantu penyampaian pesan pembelajaran (Rifa'i dan Anni, 2011). Jenis media menurut sifatnya dibagi menjadi tiga, yaitu media auditif, media visual, dan media audiovisual. Media auditif adalah media yang hanya bisa didengar saja. Contoh media auditif adalah radio, rekaman suara. Media visual adalah media yang hanya dapat dilihat saja, tidak mengandung unsur suara. Contoh media visual adalah foto, film slide, lukisan, gambar, komik, kartun, dan grafik. Media audio visual adalah media yang selain mengandung unsur suara, juga mengandung unsur gambar yang bisa dilihat. Contoh media audiovisual adalah video.

Menurut Sudjana dan Rivai (2010) komik dapat didefinisikan sebagai bentuk kartun yang mengungkapkan karakter dan memerankan suatu cerita dalam urutan yang erat hubungannya dalam gambar dan dirancang untuk memberikan hiburan kepada para pembaca. Komik adalah suatu sajian cerita dengan seri gambar yang lucu. Buku komik menyediakan cerita-cerita yang sederhana, mudah ditangkap dan dipahami lainnya, sehingga sangat digemari baik oleh anak- anak maupun orang dewasa.

Karakteristik komik menurut Sudjana dan Rivai (2010) bahwa komik terdiri ada atas berbagai situasi cerita bersambung dan bersifat humor. Perwatakan lain dari komik harus dikenal agar kekuatan medium ini bisa dihayati, komik memusatkan perhatian di sekitar rakyat, ceritanya mengenai diri pribadi sehingga pembaca dapat segera mengidentifikasi dirinya melalui perasaan serta tindakan dari perwatakan-perwatakan tokoh utamanya, cerita komik ringkas dan menarik perhatian, dilengkapi dengan aksi, bahkan dalam lembaran surat kabar dan buku-buku, komik dibuat lebih hidup serta diolah dengan pemakaian warnawarna utama secara bebas.

Menurut Daryanto (2013) komik pendidikan cenderung menyediakan isi yang bersifat formatif, komik pendidikan banyak diterbitkan oleh industri, dinas kesehatan, dan lembaga-lembaga nonprofit. Pendekatan kritis sangat diperlukan agar komik dapat memenuhi fungsinya sebagai media pendidikan. Kelebihan komik adalah penyajiannya mengandung unsur visual dan cerita yang kuat. Ekspresi yang divisualisasikan membuat pembaca terlibat secara emosional sehingga membuat pembaca untuk terus membacanya hingga selesai. Hal inilah yang juga menginspirasi komik yang isinya materi pelajaran. kecenderungan yang ada siswa tidak menyukai buku-buku teks apalagi yang tidak disertai gambar dan ilustrasi menarik. Padahal secara empirik siswa lebih cenderung menyukai buku yang bergambar, yang penuh warna dan divisualisasikan dalam bentuk realistis maupun kartun. Komik pembelajaran diharapkan mampu meningkatkan minat siswa untuk membaca sehingga pada akhirnya mampu meningkatkan hasil belajar siswa. Sebagai media pembelajaran, komik memiliki beberapa kelebihan. Komik mampu mendukung perkembangan imajinasi siswa sehingga siswa tidak hanya terfokus dalam belajar menghapal (Smith, 2006). Siswa dapat menemukan informasi yang ada melalui ilustrasi komik. Siswa dapat didorong untuk belajar mandiri dengan membaca dan memahami informasi yang ada di dalam komik. Menurut Daryanto (2013), komik memiliki beberapa kelebihan diantaranya mampu mendukung perkembangan imajinasi siswa dalam pembelajaran sehingga siswa tidak hanya terfokus dengan belajar menghafal (rote learning), penggunaan ilustrasi dalam komik 
dapat meningkatkan kemampuan analisis siswa dan menemukan informasi yang terdapat didalamnya. Media komik dapat merangsang minat siswa dalam mempelajari materi yang disajikan dalam komik. Melalui media komik, siswa menjadi lebih tertarik. Karena media komik adalah media yang banyak disukai anakanak. Selain penuh dengan gambar, komik juga mampu menyampaikan materi/tujuan pembelajaran dengan lebih menyenangkan. Secara tidak sadar dengan membaca komik siswa telah mempelajari materi yang ingin disampaikan oleh guru. Menurut Daryanto (2013) secara empirik siswa lebih tertarik untuk membaca buku bergambar dari pada buku-buku teks. Melalui ekspresi yang divisualisasikan membuat pembaca untuk terus membacanya hingga selesai. Selain itu dengan membaca komik, kemampuan membaca siswa dan penguasaan kosa kata jauh lebih banyak dari siswa yang tidak menyukai komik. Tujuan dari penelitian ini adalah (1) untuk mengetahui bagaimana penerapan media komik dalam pembelajaran matematika di sekolah dasar, (2) untuk mengetahui apakah media komik dapat membantu dalam peningkatan kualitas pembelajaran matematika di sekolah dasar..

\section{METODE PENELITIAN}

Penelitian ini merupakan penelitian payung bagi penelitian mahasiswa PGSD tentang penerapan media komik pada pembelajaran matematika di SD. Penelitian ini bersifat deskriptif sehingga penilitian ini merupakan penelitian kualitatif. Penelitian ini fokus pada media komik dan implementasinya pada pembelajaran matematika di sekolah dasar. Penelitian ini mengungkap tentang penerapan media komik dalam proses belajar mengajar. Penelitian ini dilakukan di SDN Gajahmungkur 02 Semarang, SDN Gunungpati 02 Semarang, SDN Petompon 02 Semarang. Ketiga penelitian yang dipayungi merupakan penelitian tindakan kelas.

\section{HASIL DAN PEMBAHASAN}

$\begin{array}{ccc}\text { Menurut } & \text { Susanto } & \text { (2013) } \\ \text { mengungkapkan } & \text { secara umum tujuan }\end{array}$ pembelajaran matematika di sekolah dasar adalah agar siswa mampu dan terampil menggunakan matematika. Menurut Karso (2011) dalam memaparkan langkah-langkah pembelajaran matematika di Sekolah Dasar, yaitu: (1) Konsep dasar (penanaman konsep), merupakan materi-materi atau bahan-bahan dari sekumpulan bahasan atau semesta bahasan, dan umumnya merupakan materi baru bagi para siswa yang mempelajarinya. Oleh karena itu, setelah konsep dasar ditanamkan maka konsep dasar ini akan menjadi prasyarat dalam memhami konsep-konsep berikutnya, (2) Konsep yang berkembang (pemahaman konsep), merupakan sifat atau penerapan dari konsep-konsep dasar. Konsep yang berkembang ini merupakan kelanjutan dari konsep dasar dan dalam mempelajarinya memerlukan pengetahuan tentang konsep dasar, (3)Konsep yang harus dibina keterampilannya (pembinaan keterampilan), merupakan konsep-konsep dasar atau konsep-konsep yang berkembang. Pembelajaran pembinaan keterampilan bertujuan agar siswa lebih terampil dalam menggunakan berbagai konsep matematika.

Gerlach dan Ely (dalam Hamdani, 2011) mengatakan bahwa media apabila dipahami secara garis besar, media adalah manusia, materi, atau kejadian yang membangun kondisi agar siswa mampu memperoleh pengetahuan, keterampilan, atau sikap. Guru, buku teks, dan lingkungan sekolah merupakan media. Secara khusus, pengertian media dalam proses belajar mengajar cenderung diartikan sebagai alat-alat grafis, fotografis, atau elektonik untuk menangkap, memproses, dan menyusun kembali informasi visual atau verbal. Media pembelajaran bisa dikatakan sebagai alat yang bisa merangsang siswa untuk terjadinya proses belajar. Menurut Djamarah (2010) menjelaskan bahwa media adalah alat bantu apa saja yang dapat dijadikan sebagai penyalur pesan guna mencapai tujuan pengajaran. Sedangkan Hamdani (2011) berpendapat media adalah komponen sumber belajar atau wahana fisik yang mengandung materi instruksional di lingkungan siswa, yang dapat merangsang siswa untuk belajar. Adapun media pembelajaran adalah media yang membawa pesan-pesan atau informasi yang bertujuan instruksional atau mengandung maksud-maksud pengajaran. Sanjaya (dalam Hamdani, 2011) menyatakan bahwa media pembelajaran meliputi perangkat keras yang dapat mengantarkan pesan dan perangkat lunak yang mengandung pesan. Berdasarkan pendapat para ahli di atas, dapat disimpulkan bahwa media pembelajaran adalah alat yang digunakan oleh guru dalam kegiatan pembelajaran untuk menyampaikan pesan guna memudahkan siswa dalam mempelajari materi yang sedang diajarkan sehinggan tujuan pembelajaran dapat tercapai.

Media pembelajaran adalah segala sesuatu yang dapat digunakan untuk menyalurkan pesan dari pengirim ke pengirim sehingga merangsang pikiran, perasaan, perhatian dan minat serta kemauan peserta didik sedemikian rupa sehingga proses belajar terjadi 
dalam rangka mencapai tujuan pembelajaran secara efektif (Sukiman, 2012). Sedangkan Rifa'i dan Anni (2011) menjelaskan media pembelajaran adalah alat atau wahana yang digunakan pendidik dalam proses pembelajaran untuk membantu penyampaian pesan pembelajaran. Sebagai salah satu komponen sistem pembelajaran berfungsi meningkatkan peranan strategi pembelajaran.

Secara psikologis, anak akan lebih mudah mempelajari hal yang kongkrit ketimbang yang abstrak. Menurut Sanjaya (2011) media pembelajaran dapat diklasifikasikan menjadi beberapa dilihat dari sudut pandangnya. Dilihat dari sifatnya, media dibagi menjadi: (a)Media auditif, yaitu media yang hanya dapat didengar saja, seperti radio, rekaman suara, (b) Media visual, yaitu media yang hanya dapat dilihat saja, tidak mengandung unsur suara, seperti foto, lukisan, gambar, komik, dan sebagainya, (c)Media audiovisual, yaitu media yang selain mengandung unsur suara, juga mengandung unsur gambar yang bisa dilihat. Dilihat dari kemampuan jangkauannya, media dapat dibagi menjadi: (a) Media yang memiliki daya input yang luas dan serentak seperti televisi, (b) Media yang mempunyai daya input yang terbatas oleh ruang dan waktu seperti film, video, dan sebagainya. Dilihat dari cara atau teknik pemakaiannya yaitu: (a) Media yang dapat diproyeksikan seperti slide, film strip, dan sebagainya, (b) Media yang tidak diproyeksikan seperti gambar, lukisan, dan sebagainya. Ada berbagai jenis media pembelajaran yang biasa digunakan dalam proses pengajaran, diantaranya: 1) media grafis berfungsi menyalurakan pesan dari sumber ke penerima pesan. Jenis media grafis diantaranya : gambar atau foto, sketsa, diagram, komik, bagan atau chart; 2) teks, media ini membantu siswa untuk focus pada materi karena cukup endengarkan tanpa melakukan aktivitas lain yang menuntut konsentrasi; 3) audio, memudahkan dalam mengidentifikasi objek-objek, mengklasifikasikan objek, mamu menunjukkan hubungan spasial dari suatu objek, membantu menjelaskan konsep abstrak menjadi konkret; 4) media grafik mampu menunjukkan objek dengan ide, menjelaskan konsep yang sulit, menjelas-kan konsep abstrak menjadi konkret, menunjukkan dengan jelas suatu langkah yang procedural; 5) media animasi menyediakan suatu tiruan yang apabila dilakukan pada peralatan yang sesungguhnya terlalu mahal atau berbahaya; 6) media video cocok untuk mengajarkan materi dalam ranah perilaku atau psikomotorik (Hamdani, 2011).
Secara umum, media pembelajaran memiliki beberapa fungsi, diantaranya adalah sebagai berikut: (1) menyaksikan benda yang ada atau peristiwa yang terjadi pada masa lampau; (2) mengamati benda atau peristiwa yang sukar dikunjungi, baik karena jaraknya jauh, berbahaya, atau terlarang; (3) memperoleh gambaran yang jelas tentang benda atau hal-hal yang sukar diamati karena ukurannya terlalu besar atau terlalu kecil; (4) mendengar suara yang sukar ditangkap dengan telinga secara langsung; (5) mengamati dengan teliti binatangbinatang yang sukar diamati secara langsung karena sukar ditangkap; (6) mengamati peristiwa-peristiwa yang jarang terjadi atau berbahaya untuk didekati; (7) mengamati dengan jelas benda-benda yang mudah rusak atau sukar diawetkan; (8) dengan mudah membandingkan sesuatu; (9) dapat melihat secara cepat suatu proses yang berlangsung secara lambat; (10) dapat melihat secara lambat gerakan-gerakan yang berlangsung secara cepat; (11) mengamati gerakan-gerakan mesin atau alat yang sukar diamati secara langsung; (12) melihat bagian-bagian yang tersembunyi dari suatu alat; (13) melihat ringkasan dari suatu rangkaian pengamatan yang panjang atau lama; (14) dapat menjangkau audien yang besar jumlahnya dan mengamati suatu objek secara serempak; (15) dapat belajar sesuai dengan kemampuan, minat, dan temponya masingmasing (Hamdani, 2011).

Media komik adalah salah satu bentuk media grafis (visual) yang menekankan pada indera penglihatan siswa dalam menerima pesan yang disampaikan oleh guru dan berbentuk cerita. Penggunaan komik dalam pengajaran sebaiknya dipadu dengan metode mengajar, sehingga komik akan dapat menjadi media yang efektif. Menurut Daryanto (2013) komik adalah suatu bentuk sajian cerita dengan seri gambar yang lucu. Komik adalah suatu kartun yang mengungkapkan suatu karakter dan memerankan suatu cerita dalam urutan yang erat, dihubungkan dengan gambar dan dirancang untuk memberikan hiburan kepada pembaca (Sudjana dan Rivai, 2010). Dalam penggunaan media komik secara efektif pada saat proses belajar mengajar, guru diwajibkan untuk menggunakan motivasi potensial dari buku komik yang dipadu dengan metode mengajar, sehingga komik akan dapat menjadi alat pengajaran yang efektif (Sudjana dan Rivai, 2010). Dengan demikian komik akan dapat difungsikan sebagai media instruksional edukatif. Buku komik menyediakan cerita-cerita yang sederhana, mudah ditangkap dan mudah dipahami siswa, sehingga sangat digemari baik 
oleh anak-anak maupun orang dewasa. Daryanto juga mengungkapkan bahwa melalui komik siswa akan memiliki penguasaan kosakata lebih banyak dibandingkan yang lain, mengandung unsur visual dan cerita yang kuat, mampu mendukung perkembangan imajinasi siswa dalam pembelajaran sehingga siswa tidak hanya terfokus dengan belajar menghafal (rote learning), penggunaan ilustrasi dalam komik dapat meningkatkan kemampuan analisis siswa terhadap suatu literatur dan menemukan informasi yang terdapat didalamnya, serta mengarahkan siswa untuk belajar mandiri dengan membaca dan memahami informasi yang ada di dalam komik (Daryanto, 2013).

Daryanto (2013) mengungkapkan menurut fungsinya, komik dibagi menjadi dua, yaitu: (a)Komik komersial, jauh lebih diperlukan dipasaran, karena bersifat personal, menyediakan rumor yang kasar, dikemas dengan bahasa percakapan dan bahasa pasaran, memiliki kesederhanaan jiwa dan moral, (b)Komik pendidikan, banyak diterbitkan oleh industri, dinas kesehatan, dan lembaga-lembaga non-profit. Pendekatan kritis sangat diperlukan agar komik dapat memenuhi fungsinya sebagai media pendidikan. Smith (2006) juga mengemukakan bahwa terdapat dua jenis komik, yaitu komik strip (comic strip) dan comic book. Komik strip adalah komik yang menggunakan beberapa panel, biasanya terdiri dari tiga sampai empat panel. Cerita yang disampaikan bisa berpusat pada suatu karakter dan memiliki rangkaian cerita yang berhubungan. Komik strip biasanya dibuat oleh penulis tunggal dan lebih menekankan pada humor. Pada dasarnya comic book adalah kumpulan dari beberapa komik strip yang dikemas menjadi bentuk menyerupai buku. Pembuatan comic book biasanya melibatkan beberapa orang yang bertugas untuk menulis naskah, membuat sket atau karakter, dan memberi warna.

Sebagai suatu media pembelajaran, komik memiliki beberapa kelebihan. Menurut pendapat Smith (2006), diketahui bahwa komik memiliki keunggulan sebagai berikut: (a)Melalui kombinasi teks dan ilustrasi, komik merupakan media yang tepat bagi siswa dengan karakter belajar visual yang baik, (b)Mengarahkan siswa untuk belajar mandiri dengan membaca dan memahami informasi yang ada di dalam komik, (c)Selain itu, komik merupakan salah satu wujud penyajian materi pembelajaran di kelas yang dapat menampilkan permasalahan-permasalahan yang relevan dengan peristiwa atau kejadian nyata di kehidupan sehari-hari (Smith, 2006: 7). Selain itu, komik merupakan salah satu wujud penyajian materi pembelajaran di kelas yang dapat menampilkan permasalahan-permasalahan yang relevan dengan peristiwa atau kejadian nyata di kehidupan sehari-hari (Smith, 2006). Hal ini dapat membantu guru dalam menyampaikan konsep-konsep yang abstrak ke dalam bentuk yang lebih konkret dan menarik bagi siswa. Komik dapat membantu siswa dalam mencari informasi baru dan meningkatkan keaktifan siswa dalam proses belajarnya. Komik menjadi pilihan karena adanya kecenderungan banyak siswa lebih menyenangi bacaan media hiburan seperti komik dibandingkan dengan menggunakan waktu mereka untuk belajar atau mengerjakan tugas rumah. Komik adalah sebuah media yang menyampaikan cerita dengan visualisasi atau ilustrasi gambar, dengan kata lain komik adalah cerita bergambar, dimana gambar berfungsi untuk pendeskripsian cerita agar si pembaca mudah memahami cerita yang disampaikan oleh si pengarang (Haryono, 2013). Kelebihan media komik: (a) peranan pokok dari buku komik adalam instruksional adalah kemampuannya dalam menciptakan minat peserta didik; (b) membimbing minat baca yang menarik pada peserta didik; (c) komik daapat berfungsi sebagai jembatan untuk menumbukan minat baca; (d) komik menambah pembendaharaan kata-kata pembacanya; (e) mempermudah anak didik menangkap hal-hal atau rumusan yang abstrak; (f) dapat mengembangkan minat baca anak dan salah satu bidang studi yang lain. Kelemahan media komik: (a) guru harus menggunakan motivasi poensi buku-buku komik, tetapi jangan berhenti hanya sampai disitu saja, apabila minat baca telah dibangkitkan cerita bergambar harus dilengkapi oleh materi bacaan film, gambar foto, percobaan serta berbagai kegiatan yang kreatif (Sudjana dan Rivai, 2010:68); (b) kemudahan membaca komik menyebabkan penolakan-penolakan atas buku-buku yang tidak bergambar.

Untuk mengoptimalkan pemberdayaan komik sebagai media pembelajaran, maka pesan pembelajaran yang hendak disampaikan harus memenuhi syarat-syarat berikut: (a)Pesan pembelajaran harus meningkatkan motivasi pemelajar, (b)Isi dan gaya penyampaian pesan juga harus merangsang pemelajar memproses apa yang dipelajari serta memberikan rangsangan belajar baru, (c)Pesan pembelajaran yang baik akan mengaktifkan pemelajar dalam memberikan umpan balik (Haryono, 2013).

Peneliti memperoleh data hasil penelitian dari hasil penelitian mahasiswa yang dipayungi yang sudah dilakukan. Dari ketiga 
penelitian yang dilakukan oleh mahasiswa, semuanya menerapkan media komik pada pembelajaran matematika di sekolah dasar. Sub penelitian yang pertama dilakukan oleh Tika Aprilia. Media komik ini diimplementasikan dengan model CTL Variasi Talking Stick. Sub penelitian kedua dilakukan oleh Ulfatu Solikhah. Media komik ini diimplementasikan dengan model PjBl Variasi Bamboo Dancing. Sub penelitian ketiga dilakukan oleh Widi Kurniawati. Media komik ini diimplementasikan dengan model CTL Variasi Snowball Throwing.

Ketiga sub penelitian tersebut dilaksanakan di SD Negeri di kota Semarang terutama di kelas tinggi (kelas IV dan V) yang terfokus pada implementasi media komik pada pembelajaran matematika di sekolah dasar, tetapi ketiganya mengembangkan media komik yang berbeda. Media komik yang dikembangkan disesuaikan dengan model pembelajaran yang digunakan. Karena model pembelajaran yang digunakan berbeda maka sintaks pembelajaran matematika dari ketiga penelitian ini juga ada perbedaan. Berikut perbedaan sintaks pembelajarannya. Sintaks pelaksanaan pembelajaran dalam sub penelitian yang pertama (CTL variasi talking stick berbantuan media komik) adalah: (a)Mengkondisikan siswa untuk mengikuti pembelajaran, (b)Siswa diminta untuk berbagi pengalaman kontekstual yang berhubungan dengan materi yang akan dipelajari, (c)Kemudian siswa diberikan komik untuk dibaca dan dipahaminya, (d)Setelah selesai memahami isi komik, siswa diminta untuk menemukan konsep materi yang tersirat dan memecahkan permasalahan dalam komik jilid 1, (e)Guru memperjelas konsep materi yang terdapat dalam komik dan memberikan kesempatan kepada siswa untuk bertanya, (f)Siswa dikelompokkan menjadi 5 kelompok, (g)Setiap kelompok diminta untuk menyelesaikan permasalahan yang terdapat di dalam komik jilid 2 yang telah dibagikan guru dan menuliskan jawabannya secara individu meskipun berdiskusi secara kelompok, (h)Siswa mempresentasikan hasil diskusinya dengan metode talking stick, (i)Siswa bersama dengan guru merefleksikan dan mengevaluasi hasil pemecahan masalah (jawaban) setiap siswa, (j)Siswa bersama guru menyimpulkan materi yang telah dipelajari, (k)Guru menutup pembelajaran dan memberikan penilaian yang sebenarnya (autentik) dengan berbagai cara. Sintaks pelaksanaan pembelajaran dalam sub penelitian yang kedua ( $\mathrm{PjBl}$ variasi bamboo dancing berbantuan media komik) adalah: (a)
Siswa diberi komik dan diminta untuk membaca dan memahaminya, (b) Guru memberikan pertanyaan kepada siswa untuk memberi penugasan kepada siswa, (c) Guru dan siswa secara kolaboratif merencanakan proyek, (d) Guru dan siswa secara kolaboratif menyusun jadwal aktivitas dalam menyelesaikan proyek sesuai dengan komik, (e) Guru bertanggung jawab memonitor terhadap aktivitas siswa selama penyelesaian proyek, (f) Guru membagi Separuh kelas (atau seperempat jika jumla siswa terlalu banyak) berdiri berjajar, (g) Separuh kelas lainnya berjajar dan menghadap jajaran yang pertama, (h) Guru menilai kemajuan siswa saat siswa secara berpasangan berbagi informasi, (i) Siswa pindah ke ujung lainnya pada jajaran yang lain sehingga jajaran akan bergeser, (j) Guru dan siswa melakukan refleksi dengan menunjukkan cara yang benar untuk memecahkan masalah dan hasil proyek yang sudah dijalankan. Pelaksanaan pembelajaran dalam sub penelitian ketiga (CTL variasi Snowball Throwing berbantuan media komik) adalah: (a)Guru menyiapkan dan membagikan komik kepada siswa. (Tahap Persiapan), (b)Siswa mengkonstruk konsep melalui komik yang dibagikan. (Konstruktivisme), (c)Siswa melakukan penemuan terhadap masalah pada komik. (Inkuiri), (d)Guru bertanya tentang masalah yang ada pada komik. (Bertanya), (e)Siswa berdiskusi dengan membentuk kelompok beranggotakan 7 orang tiap kelompok yang heterogen berdasarkan tingkat kemampuan siswa. Acuan pengelompokkan siswa menggunakan hasil ulangan harian pada bab sebelumnya. (Masyarakat Belajar), (f)Siswa mempresentasikan hasil diskusi. (Pemodelan), (g)Siswa melakukan kegiatan Snowball throwing, (h)Guru dan siswa menyimpulkan pembelajaran yang telah dipelajari. (Refleksi), (i)Siswa mengerjakan evaluasi. (Penilaian Sebenarnya)

Ketiga komik tersebut merupakan komik pendidikan, karena digunakan dengan tujuan pendidikan. Ketiga komik tersebut juga merupakan buku komik karena tersusun dari beberapa komik strip dan dibuat menyerupai buku. Media komik tersebut digunakan untuk menarik minat baca siswa. Meskipun ketiga penelitian tersebut memiliki sintak yang berbeda namun dalam pelaksanaannya terdapat kesamaan yaitu komik diberikan pada awal pembelajaran dan siswa diminta untuk memahami materi dan mengkonstruk konsep melalui komik. Hasil sub penelitian yang pertama menyatakan bahwa dengan model pembelajaran CTL variasi talking stick berbantuan media komik dapat meningkatkan 
kualitas pembelajaran matematika pada siswa kelas V, meliputi keterampilan guru, aktivitas siswa, iklim pembelajaran, materi pembelajaran, media pembelajaran, dan hasil belajar. Hasil sub penelitian yang kedua menyatakan bahwa dengan model PjBL variasi Bamboo Dancing dengan media komik dapat meningkatkan kualitas pembelajaran pada siswa kelas IV SDN Gunungpati 02 meliputi peningkatan keterampilan guru, aktivitas siswa, iklim, materi media dan hasil belajar sesuai kriteria yang sudah ditentukan. Hasil sub penelitian yang ketiga menyatakan bahwa dengan $C T L$ variasi Snowball Throwing berbantuan media komik meningkatkan kualitas pembelajaran matematika yang meliputi keterampilan guru, aktivitas siswa, kualitas iklim pembelajaran, kualitas materi pembelajaran, kualitas media pembelajaran, dan hasil belajar siswa kelas IVA SDN Petompon 02 Semarang. Dari ketiga penelitian tersebut diperoleh hasil yang sama yaitu media komik dapat membantu dalam peningkatan kualitas pembelajaran matematika. Hasil penelitian ini memperkuat penelitian sebelumnya. Rasiman dan Siska (2014) menjelaskan bahwa penggunaan media komik dalam pembelajaran matematika dapat meningkatkan minat baca siswa, berpikir kritis, dan menanamkan nilai karakter yang positif. Penelitian yang dilakukan oleh Sastra Negara (2014) menyimpulkan bahwa penggunaan media komik cukup dapat memotivasi siswa dalam belajar sehingga kesan negatif siswa terhadap pelajaran matematika yang sulit dan tidak menyenangkan bahkan sebagai momok dalam pembelajaran dapat dihilangkan berubah menjadi pelajaran matematika yang menyenangkan sehingga berakibat minat dan antusias belajar siswa menjadi meningkat yang akhirnya bermuara pada peningkatan hasil belajar matematika siswa. Penggunaan media komik ini juga dapat dipadukan pada modelmodel pembelajaran sebagai sentuhan atau pewarna dalam proses pembelajaran dan juga dapat diselingi dengan permainan matematika. Kita sebagai guru juga dapat menanamkan nilainilai karakter yang baik dalam cerita tokohtokoh komik yang kita buat.

\section{SIMPULAN}

Dari hasil penelitian ketiga mahasiswa serta pembahasan tentang implementasi media permainan pada pembelajaran matematika di sekolah dasar, maka dapat ditarik kesimpulan sebagai berikut: (1) Komik diberikan pada awal pembelajaran dan siswa diminta untuk memahami materi dan mengkonstruk konsep melalui komik., (2) Media komik dapat membantu dalam peningkatan kualitas pembelajaran matematika.

\section{DAFTAR PUSTAKA}

Daryanto. 2013. Media Pembelajaran Peranannya sangat Penting dalam Mencapai Tujuan Pembelajaran. Yogyakarta: Gava Media.

Djamarah, Syaiful Bahri dan Aswan Zain. 2010. Strategi Belajar Mengajar. Jakarta: Rineka Cipta.

Depdiknas. 2007. Kajian Kebijakan Kurikulum Mata Pelajaran Matematika. Jakarta : Pusat Kurikulum Balitbang Depdiknas.

Hamdani. 2011. Strategi Belajar Mengajar. Bandung: Pustaka Setia.

Haryono. 2013. Pembelajaran IPA yang Menarik dan Menyenangkan. Yogyakarta: Kepel Press.

Karso, dkk. 2011. Pendidikan Matematika 1. Jakarta: Universitas Terbuka.

Rasiman dan Siska P, Agnita. 2014. Development of Mathematics Learning Media E-Comic Based on Flip Book Maker to Increase the Critical Thinking Skill and Character of Junior High School Students. International Journal of Education and Research Vol 2 No 11: 535-544

Rifa'i, Achmad dan Catharina Tri Anni. 2011. Psikologi Pendidikan. Semarang: UNNES PRESS.

Sanjaya, Wina. 2011. Strategi Pembelajaran Berorientasi Standar Proses Pendidikan. Jakarta: Kencana Prenada Media.

Sastra Negara, Hasan. 2014. Penggunaan Komik Sebagai Media Pembelajaran Terhadap Upaya Meningkatkan Minat Matematika Siswa Sekolah Dasar (SD/MI). Jurnal Terampil Volume 3 No 3:66-76.

Smith, Andrew. 2006. Teaching With Comics. University of Lethbridge.

Sudjana, Nana dan Ahmad Rivai. 2010. Media Pembelajaran. Bandung: Sinar Baru Algesindo. 